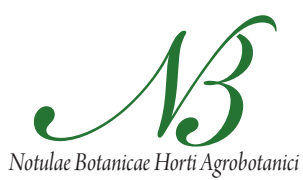

Cluj-Napoca

\title{
Agronomic Properties Assessed for Population of Recombinant Inbred Lines of Rye (Seceale cereale L.) with Known Responses to Nutrient Deficiency Stress at the Seedling Stage
}

\author{
Mitosz SMOLIK \\ West Pomeranian University of Technology, Department of Plant Genetics, Breeding and \\ Biotechnology, Stowackiego St.17, 71-434 Szczecin,Poland; msmolik@zut.edu.pl
}

\begin{abstract}
The experiment was established and carried out in light and slightly acidic soil in the years 2008-2010. The research material included one hundred thirty-eight RILs $\left(\mathrm{F}_{8: 10}\right)$ of rye with known response to nutrient stress were determined at the seedling stage obtained in vitro in mature embryos cultures and in two parental inbred lines and $F_{1}$. The following factors were determined in the full maturity stage of each RIL: plant height, spike length, plant tillering, spikelet number per spike, grain number per spike, spike fertility, grain weight per spike, grain weight per plant and 1000 grain weight. Differences in the examined traits were found between parental inbred lines, and the heterosis effect was observed in $\mathrm{F}_{1}$ hybrid. The range of variability of the examined functional traits demonstrated in the population of RILs proved the transgression effect. The analyzed RILs were arranged into six groups and described with the use of Ward's agglomerative method and grouping variables: spike fertility, grain weight per spike and per plant, thousand grain weight. Significant differences were found among other things between spike morphology and fertility traits and yield per a plant. The possibility of selection of RILs with extreme traits described both in the field and laboratory experiments in comparison with known tolerance to nutrient stress was described. The obtained correlation coefficients for the examined functional traits of RILs were in accordance with those published in reference literature. The correlation coefficients determined for selected seedling traits from the laboratory experiment and for selected traits of a mature plant may prove the usefulness of the test in studies on selection of genotypes desired for sustainable agriculture or for research on heritability of traits of tolerance to nutrient stress.
\end{abstract}

Keywords: agronomic properties, nutrient deficiencies, RIL, Secale cereale, selection

\section{Introduction}

Breeding programs are implemented for economically important cultivated plant species, aiming at obtaining cultivars tolerant to stresses caused by biotic and abiotic factors (Górny et al., 2011, Messmer et al., 2011; Wolfe et al., 2008), including stress of drought (Rapacz et al., 2010; Sayar et al., 2010), cold (Rapacz et al., 2008), salinity (Sayar et al., 2010), toxic influence of aluminum (Anioł and Gustafson, 1984) or nutrient deficiencies (Ciepły and Oracka, 2000; Liu et al., 2008; Lynch, 2007; Rzepka-Plevneš et al., 1997a, 1997b; Rzepka-Plevneš and Tomczak, 1998). Since plants are able to utilize only about $30 \%$ of available nitrogen doses, high doses of plant mineral fertilization were found to increase only the cost of plant cultivation (Lynch, 2007; Raun and Johnson, 1999; Zhou and Chen, 2002). The remaining doses contribute to ground water contamination (Raun and Johnson, 1999), eutrophication of rivers and lakes, and adversely affect produced food (Lynch, 2007; Zhou and Chen, 2002).

A way to minimize the mentioned threats is introduction of cultivars tolerant to stress to cultivation, including to stress caused by nutrient deficiencies (Górny et al.,
2011; Löschenberger et al., 2008; Rzepka-Plevneš et al., 1997b, Wolfe et al., 2008). It was demonstrated that effective utilization of nitrogen ions by a plant depends on availability of potassium ions (Ashraf and Harris, 2005; Tsay et al., 2011). Species of cultivated plants have a wide range of genotypic variability predisposing a plant to growth under the conditions of decreased mineral fertilization, and an important factor that determines this adaptation is a complex and genetically complicated trait - root architecture. Selection of genotypes adapted for growth under conditions of nutrient deficiencies is carried out depending on root system (Löschenberger et al., 2008; Lynch, 2007; Messmer et al., 2011; Tuberosa and Salvi, 2007). Genotypes develop a long and well-developed root system demonstrate high effectiveness of exploration of deeper soil layers (Lynch, 2007), thereby increasing a chance of avoiding drought or obtaining nutrients (Bloom et al., 1985). According to many authors, the assessment of genotype response to nutrient stress carried out under laboratory conditions in the seedling stage is reflected in a similar response in the plant maturity stage (Liu et al., 2008; Messmer et al., 2011), although some authors have different opinions (Bolanõs et al., 1993). 
Cultivated rye (Secale cereale L. ssp. Cereale) is a species adapted to growth in poor soils. In the case of its cultivation the problem of over-fertilization practically does not exist (Arseniuk and Oleksiak, 2003; Geiger and Miedaner, 2009; Górny et al., 2011). However, it should be noted that its cultivation is displaced by triticale from good and medium soils into poorer soils (Dmochowska, 2011; Górny et al., 2011; Rzepka-Plevneš et al., 1990). Such a situation is taking place in the countries of the RYE-BELT region. In Poland in 2000 rye accounted for $17.2 \%$ of all crops, in $2010-10.1 \%$. In the case of triticale the situation is opposite - in 2000 it accounted for $5.6 \%$ of total crops, while in 2010 - already 12.5\% (Dmochowska, 2011).

Rzepka-Plevnešetal. (1997a, 1997b) showed great variability within open-pollinated populations, strains or inbred lines in terms of their response to nutrient stress caused by nitrogen and potassium deficiencies in in vitro cultures of mature embryos as well as in hydroponics (RzepkaPlevneš and Tomczak, 1998), while their assessment of the functional value of selected populations (genotypes) both in the pot (Rzepka-Plevneš and Tomczak, 1998) and field experiment showed usefulness of the methods in selection (Rzepka-Plevneš and Kulpa, 1996). Rzepka-Plevneš et al. (1997b) stated that the populations selected under low $\mathrm{N}$ supply in soil were characterized by high spike productivity, TGW and grain field per pot. Similar results for corn were presented by Liu et al. (2002) and Tuberosa et al. (2002), who demonstrated significant correlations between root system morphology and NUE (Nutrient-Use Efficiency), and at the same time identified a range of QTLs linked to development of that trait (Liu et al., 2008; Malamy 2005; Tuberosa and Salvi, 2007).

Possessing genotypes tolerant to stress caused by nutrient deficiencies is a significant element of the breeding processes aiming at obtaining new cultivars of cultivated plants, including cereals, adapted to cultivation in a sustainable agriculture system (Górny et al., 2011; Löschenberger et al., 2008; Rzepka-Plevneš et al., 1997b; Wolf et al., 2008). Such genotypes are an interesting material for research on mechanisms of heritability of the trait. Segregating descendant populations $\left(\mathrm{F}_{2}\right)$ and also combinations of highly homogeneous RILs obtained as a result of crossing genotypes extremely different in the examined trait facilitate identification of molecular markers linked to QTL of a given trait or identification of major genes determining it (Lammerts van Bueren et al., 2010; Masojć et al., 2009).

The aim of the present study was to describe selected agronomic traits of the population of 138 recombinant inbred lines of rye in the field experiment and to make an attempt at describing correlation relationships between morphology of a mature plant and response of individual RILs to nutrient stress in the seedling stage, determined in some other experiment.

\section{Material and methods}

The research was carried out in the years 2008-2010 in the vegetation hall of the Agricultural Academy in Szczecin, at present named the West Pomeranian University of Technology in Szczecin (Poland).

\section{Plant material}

Research material included a population of 138 recombinant inbred lines (RILs) of rye derived from the $\mathrm{F}_{2.3}$ generation obtained as a result of crossing inbred lines 153/79-1 and Ot1-3 (each, $S>23$ ). Characterization and origin of parental lines were presented by Rzepka-Plevnes et al. (1997a). RILs of rye were derived from the $\mathrm{F}_{3}$ generation with the use of the SSD method (Single Seed Descent). Characterization of biometric traits of RILs was started after six years of inbreeding and addressed the subsequently obtained $\mathrm{F}_{8 \cdot 10}$ generations. Also parental lines and annually obtained $\mathrm{F}_{1}$ hybrids were under observation.

\section{Field conditions}

The experiment was established in light soil with slightly acidic reaction $(\mathrm{pH} \mathrm{KCl} \approx 5.8)$ in a stand after many-year rye cultivation. Fertilization with nitrogen was applied pre-sowing during plowing in the dose of respectively $30 \mathrm{~kg} \mathrm{~N} \mathrm{ha}^{-1}$ and as top-dressing in the tillering stage in the dose of $15 \mathrm{~kg} \mathrm{~N} \mathrm{ha}^{-1}$. Fertilization with phosphorus and potassium was not used because soil analyses showed $\mathrm{P}$ in the amount of $24, \mathrm{~K}-7.6, \mathrm{Mg}-4.8, \mathrm{Mn}-15 ; \mathrm{Cu}$ $0.89 ; \mathrm{Zn}-16$ and Fe in the amount of $120 \mathrm{mg}$ per $100 \mathrm{~g}$ of soil collected for the analysis.

\section{Experiment design}

Biometric traits of RILs were assessed in a microplot experiment established in the system of complete randomization in three replications, i.e. two-row plots with the length of $90 \mathrm{~cm}$ and spacing of $18 \mathrm{~cm}$. The plants were manually planted in the 1-2 leaf stage, depending on weather conditions, in the last week of September or in the first week of October. Ten plants were growing in one row. The plants were protected against diseases and pests with the use of spraying with the preparations: Punch Bis 400 EC, Calypso 480 SC, Mospilan 20 SP and Mesurol Schneckenkorn $04 \mathrm{~GB}$ according to the doses recommended by the producers. Weeds were removed manually and no growth regulators were applied. In the earing stage, isolators were put on spikes of the longest stalks of six plants uniform in height of each RIL. Also isolators were put on all spikes of three out of six representative plants of a given RIL. Grain of one of them was intended for establishing the experiment in the following year. In the case of an insufficient amount of grain required for establishing the experiment, a lower number of plants was sown in replications. 
278

\section{Measurement of plant traits}

For these plants the following traits were assessed in the full maturity stage: plant high $(\mathrm{PH})$ in $\mathrm{cm}$; spike length $(\mathrm{SL})$ in $\mathrm{cm}$; plant tillering $(\mathrm{PT})$; spikelet number per spike (SNS); grain number per spike (GNS); spike fertility (SF) in \%; grain weight per spike (GWS) in g; grain weight per plant (GWP) in g, and 1000 grain weight (TGW) in g. Statistical analysis. The assessment of variability of the examined traits in the following years was carried out on the basis of descriptive statistics. Arithmetic mean (x), standard deviation (SD), range (D), bias and kurtosis were calculated for parental lines, $\mathrm{F}_{1}$ and the population of RILs. Two-ways analysis of variance in a completely randomized design was carried out separately for the traits of parental lines, $F_{1}(G)$, years $(Y)$ and interactions $(G \times Y)$, separately for RILs, and the results were presented in the form of syntheses. The differences between means were examined with the use of $t$-Tukey's test with $p<0.05$ and $p<0.01$. Concordance with normal distribution for individual traits of the population of RILs was illustrated on the basis of analysis of stemplots and histograms with marked normal distribution curve. Significance of deviation of trait distribution from normal distribution was analyzed with the Kolmogorov-Smirnov test. Mean values of the examined traits of RILs for the years were used to calculate simple correlation coefficients. These means were used also in cluster analysis carried out using Ward's agglomerative method with four grouping variables: SF, GWS, GWP and TGW. Cluster analysis enabled division of RILs into groups with similar values, presented as a dendrogram on the basis of scree graph, assuming the Euclidean distance criterion. The values of the examined traits within the obtained groups of RILs are presented as means and standard deviations, and the differences between the means were analyzed using $t$-Tukey's test on the basis of calculated LSD (Least Significant Difference) with $p<0.05$ and $p$ $<0.01$. Statistica 9 PL software was used for the statistical calculations.

\section{Results}

The genotype of rye inbred lines used as parental components in a combination of crossings of $F_{1}$ hybrid (153/79-1 × Ot1-3) had a highly significant influence on most of their agronomic traits (Tab. 1). Inbred line 153/79-1 had higher values of compared traits, and TGW and SF were exceptions, for which no significant differences were found between the examined lines (Tab. 1). Comparison of traits of the examined inbred lines of rye of $F_{1}$ proved that $F_{1}$ hybrid outdid the both parental inbred lines in PH, PT, GNS, SF, GWS, GWP and TGW (Table 1). In terms of SL and SNS it did not significantly differ from line 153/79-1 (Tab. 1).

The values of descriptive statistics performed for the examined agronomic traits of RILs are presented in Tab. 2.

In terms of each trait, a range of variability exceeding variability described for parental lines was demonstrated in RILs (Tab. 2). In the individual years of research the values of $C V s$ were different, on average the lowest values

Tab. 1. Characteristics of agronomic traits of inbred lines of rye and their $F_{1}$ hybrid

\begin{tabular}{|c|c|c|c|c|}
\hline \multirow{2}{*}{$\begin{array}{c}\text { Genotype } \\
\text { Trait }\end{array}$} & $153 / 79-1$ & $153 / 79-1 \times$ Ot $1-3$ & Ot1-3 & \multirow{2}{*}{$\mathrm{LSD}_{0.01}$} \\
\hline & \multicolumn{3}{|c|}{$\overline{\mathrm{X}} \pm \mathrm{S}$} & \\
\hline $\mathrm{PH}(\mathrm{cm})$ & $124 \pm 2.8 \mathrm{~b}$ & $137 \pm 4.7 \mathrm{a}$ & $95 \pm 2.1 \mathrm{c}$ & 1.69 \\
\hline $\mathrm{SL}(\mathrm{cm})$ & $9.3 \pm 0.5 \mathrm{a}$ & $9.6 \pm 0.6 \mathrm{a}$ & $6.2 \pm 0.4 \mathrm{~b}$ & 0.42 \\
\hline PT & $5.2 \pm 0.7 \mathrm{~b}$ & $6.4 \pm 1.2 \mathrm{a}$ & $3.6 \pm 0.6 \mathrm{c}$ & 0.68 \\
\hline SNS & $33.3 \pm 3.1 \mathrm{a}$ & $34.4 \pm 3.7 \mathrm{a}$ & $26.8 \pm 2.1 \mathrm{~b}$ & 2.16 \\
\hline GNS & $26.1 \pm 3.5 b$ & $47.7 \pm 8.0 \mathrm{a}$ & $21.1 \pm 3.4 \mathrm{c}$ & 4.69 \\
\hline SF (\%) & $39.7 \pm 5.9 \mathrm{~b}$ & $72.7 \pm 14.2 \mathrm{a}$ & $38.1 \pm 6.9 \mathrm{~b}$ & 6.01 \\
\hline GWS (g) & $0.7 \pm 0.1 \mathrm{~b}$ & $1.5 \pm 0.4 \mathrm{a}$ & $0.5 \pm 0.1 \mathrm{~b}$ & 0.22 \\
\hline GWP (g) & $3.5 \pm 0.8 \mathrm{~b}$ & $9.6 \pm 3.8 \mathrm{a}$ & $1.8 \pm 0.4 \mathrm{c}$ & 1.53 \\
\hline TGW (g) & $25.8 \pm 2.8 \mathrm{~b}$ & $32.2 \pm 10.1 \mathrm{a}$ & $24.3 \pm 7.2 \mathrm{~b}$ & 5.12 \\
\hline
\end{tabular}

Tab. 2. Characteristics of agronomic traits of population of RILs rye investigated in field condition in 2008-2010

\begin{tabular}{|c|c|c|c|c|c|c|c|c|}
\hline \multirow{10}{*}{ 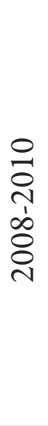 } & Traits & Mean \pm SD & Min & Max & $\mathrm{D}$ & $C V(\%)$ & Bias & Kurtosis \\
\hline & $\mathrm{PH}(\mathrm{cm})$ & $101.3 \pm 11.9$ & 73.8 & 134.5 & 60.7 & 6.2 & 0.2 & 0.5 \\
\hline & $\mathrm{SL}(\mathrm{cm})$ & $7.0 \pm 0.6$ & 5.2 & 9.5 & 3.9 & 9.5 & 0.5 & 0.7 \\
\hline & PT & $3.6 \pm 0.3$ & 2.8 & 4.1 & 1.3 & 7.5 & 0.2 & 0.1 \\
\hline & SNS & $28.1 \pm 2.1$ & 22.0 & 34.1 & 12.1 & 7.4 & 0.1 & 0.1 \\
\hline & GNS & $23.9 \pm 3.8$ & 13.5 & 33.4 & 19.8 & 15.9 & 0.1 & 0.1 \\
\hline & SF $(\%)$ & $41.7 \pm 6.9$ & 23.1 & 62.7 & 39.5 & 16.7 & 0.1 & 0.4 \\
\hline & GWS (g) & $0.5 \pm 0.1$ & 0.3 & 0.7 & 0.4 & 19.7 & 0.4 & 0.0 \\
\hline & GWP (g) & $1.6 \pm 0.3$ & 0.9 & 2.4 & 1.5 & 20.9 & 0.2 & -0.3 \\
\hline & TGW (g) & $18.6 \pm 1.6$ & 15.0 & 23.4 & 8.5 & 8.8 & 0.3 & 0.4 \\
\hline
\end{tabular}


for the population of RILs for the years 2008-2010 were found for PH (6.2\%), SNS (7.4\%) and PT (7.5\%), and the highest for GWP (20.9\%, GWS (19.7\%) and SF (16.7\%) (Tab. 2). It was also demonstrated that distribution of the examined functional traits of RILs did not significantly differ from normal distribution, and the parameters describing distribution functions of individual traits are presented in detail in Tab. 2.

The conducted analysis of variance showed relatively high values of the significant influence of genotypes of the examined RILs of rye and years of research on the values of agronomic traits of the population of RILs in comparison with the values of highly significant genotype-environment interaction (Tab. 3).

The analysis of topology of Ward's dendrogram drawn on the basis of four grouping variables (SF, GWS, GWP and TGW) revealed possibility of division of the population of 138 RILs into six groups ('a'-f') (Fig. 1).

The number of RILs in individual groups, characterization in terms of each trait, and also results of statistical analysis for differences between means are presented in Tab. 4.

Significant differences were found between the established groups for six traits: SL, SNS, GNS, SF, GWS and GWP, while for the other three traits (PH, PT and TGW) significant differences were not found (Tab. 4). It was demonstrated that on average the highest values of the examined traits (SL, GNS, SF, GWS and GWP) were attributed to the lines from the 'extreme' group - ' $\mathrm{f}$ ', and the lowest - to the lines from the 'extreme' group - 'a' (Fig. 1, Tab. 4). No significant differences were observed for SNS trait between groups 'a' and 'f' (Tab. 4).

Fig. 2 depicts characterization of agronomic traits of groups of the population of the RILs examined in the study, established with the use of Ward's agglomerative method in some other experiment (Smolik, 2013). A dendrogram, in which seven groups were distinguished ('a'' $f$ '), was created with the use of agglomeration of RILs carried out on the basis of means of traits (used as grouping variables) describing morphological response of seedlings

Ward's method

Euclidean distance

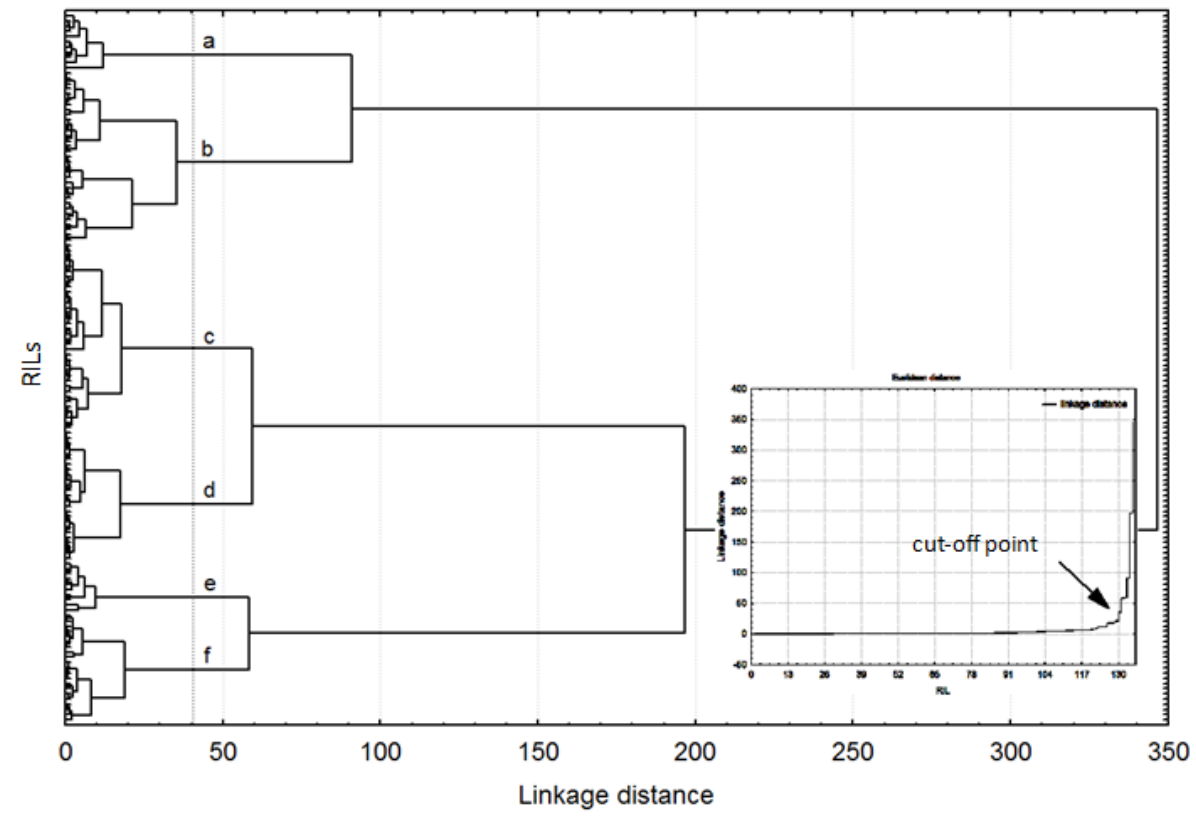

Fig. 1. Ward's dendrogram grouping ('a' - ' $\mathrm{f}$ ') the population of RILs depending on means of agronomic traits on the basis of four variables: SF, GWS, GWP and TGW into groups 'a' - 'f'. Means of agronomic traits of RILs for the years of research 2008-2010 were used for cluster analysis. The vertical lines indicate the cuts-off used to form the groups

Tab. 3. Analysis of variance for selected agronomic traits of the population of RILs examined in the field experiment in the years 2008-2010

\begin{tabular}{ccccccccccc}
\hline \multirow{2}{*}{ Source } & \multicolumn{10}{c}{ Trait } \\
\cline { 2 - 19 } & Df & PH $(\mathrm{cm})$ & SL $(\mathrm{cm})$ & PT & SNS & GNS & SF $(\%)$ & GWS $(\mathrm{g})$ & GWP $(\mathrm{g})$ & TGW $(\mathrm{g})$ \\
\hline $\mathrm{Y}$ & 2 & $171740^{* *}$ & $98^{* *}$ & $555^{* *}$ & $24789^{* *}$ & $58375^{* *}$ & $39889^{* *}$ & $45^{* *}$ & $1205^{* *}$ & $6903^{* *}$ \\
$\mathrm{G}$ & 135 & 2107 & $23.5^{* *}$ & $3.41^{* *}$ & $242^{* *}$ & $775^{* *}$ & $2608^{* *}$ & $0.43^{* *}$ & $5.79^{* *}$ & $142^{* *}$ \\
$\mathrm{Y} \times \mathrm{G}$ & 270 & $505^{* *}$ & $5.4^{* *}$ & $3.15^{* *}$ & $64^{* *}$ & $310^{* *}$ & $922^{* *}$ & $0.19^{* *}$ & $3.07^{* *}$ & $68^{* *}$ \\
E & 6934 & 37 & 0.8 & 0.56 & 14 & 61 & 190 & 0.03 & 0.57 & 20 \\
\hline
\end{tabular}

Values are the mean squares from ANOVA. ${ }^{* *}$ - high significantly different at $p<0.01$ 
Tab. 4. Means of agronomic traits of RILs depending on their affiliation to groups 'a-f' formed on the basis of cluster analysis presented as a dendrogram in Fig. 1

\begin{tabular}{|c|c|c|c|c|c|c|c|c|c|c|c|c|c|c|c|c|c|}
\hline Group & $\begin{array}{c}\text { RIL } \\
\text { number } \\
\text { in } \\
\text { group }\end{array}$ & $\mathrm{PH}(\mathrm{cm})$ & & $\mathrm{SL}(\mathrm{cm})$ & PT & & SNS & & GNS & & SF (\%) & & GWS ( & & GWP & & TGW (g) \\
\hline$a$ & 11 & $100.2 \pm 5.4$ & $\mathrm{a}$ & $6.4 \pm 0.4$ & $3.3 \pm 0.2$ & $\mathrm{a}$ & $27.2 \pm 1.6$ & $\mathrm{~b}$ & $20.5 \pm 2.1$ & $\mathrm{e}$ & $34.8 \pm 1.7$ & $\mathrm{e}$ & $0.4 \pm 0.0$ & $\mathrm{c}$ & $1.4 \pm 0.2$ & c & $18.8 \pm 1.3 \quad \mathrm{a}$ \\
\hline $\mathrm{b}$ & 33 & $101.4 \pm 6.4$ & $\mathrm{a}$ & $6.8 \pm 0.7 \quad$ bc & $3.3 \pm 0.2$ & a & $28.3 \pm 2.5$ & $\mathrm{ab}$ & $17.3 \pm 1.8$ & $\mathrm{f}$ & $28.0 \pm 2.3$ & $\mathrm{f}$ & $0.3 \pm 0.0$ & $\mathrm{~d}$ & $1.1 \pm 0.2$ & d & $18.8 \pm 2.2 \quad \mathrm{a}$ \\
\hline c & 36 & $100.0 \pm 5.3$ & a & $7.0 \pm 0.6 \quad a b c$ & $3.4 \pm 0.2$ & a & $28.7 \pm 1.8$ & $\mathrm{ab}$ & $24.8 \pm 1.5$ & c & $43.0 \pm 0.6$ & c & $0.5 \pm 0.0$ & $b$ & $1.7 \pm 0.3$ & $\mathrm{ab}$ & $18.4 \pm 1.4 \quad a$ \\
\hline d & 25 & $102.7 \pm 6.9$ & $\mathrm{a}$ & $7.0 \pm 0.6 \quad \mathrm{abc}$ & $3.4 \pm 0.3$ & $\mathrm{a}$ & $28.6 \pm 1.9$ & $\mathrm{ab}$ & $22.7 \pm 1.6$ & d & $39.5 \pm 1.2$ & d & $0.4 \pm 0.1$ & c & $1.5 \pm 0.2$ & $\mathrm{bc}$ & $19.1 \pm 1.5 \quad$ a \\
\hline e & 10 & $100.3 \pm 5.5$ & $\mathrm{a}$ & $7.5 \pm 0.7$ & $3.4 \pm 0.3$ & $\mathrm{a}$ & $29.9 \pm 1.4$ & $\mathrm{a}$ & $26.7 \pm 2.6$ & $\mathrm{~b}$ & $47.1 \pm 1.9$ & $\mathrm{~b}$ & $0.5 \pm 0.1$ & $\mathrm{ab}$ & $1.7 \pm 0.4$ & $\mathrm{a}$ & $18.0 \pm 1.2 \quad \mathrm{a}$ \\
\hline \multirow[t]{2}{*}{$\mathrm{f}$} & 21 & $101.7 \pm 7.6$ & $\mathrm{a}$ & $7.4 \pm 0.9$ & $3.3 \pm 0.2$ & $\mathrm{a}$ & $29.1 \pm 2.4$ & $\mathrm{ab}$ & $30.1 \pm 2.3$ & $\mathrm{a}$ & $55.6 \pm 2.7$ & $\mathrm{a}$ & $0.6 \pm 0.1$ & $\mathrm{a}$ & $1.9 \pm 0.2$ & $\mathrm{a}$ & $18.5 \pm 1.4 \quad a$ \\
\hline & 136 & $\mathrm{LSD}_{0.05}=6.0$ & & $\mathrm{LSD}_{0.05}=0.61$ & $\mathrm{LSD}_{0.05}=0$ & & $\mathrm{LSD}_{0.05}=2$ & & $\mathrm{LSD}_{0.05}=1.9$ & & $\mathrm{LSD}_{0.05}=1$. & & $\mathrm{LSD}_{0.05}=$ & & $\mathrm{LSD}_{0.05}=0$ & & $\mathrm{LSD}_{0.05}=1.58$ \\
\hline
\end{tabular}

of the same lines to nutrient stress (Smolik, 2013). Group A was presented as mean for 41 RILs of groups ' $a$ '- 'b', C as mean for 54 RILs of groups 'c'-'e', and E as mean for 41 RILs of groups ' $\mathrm{f}$ '- 'g' (Fig. 2).

After "marking" means of agronomic traits of individual RILs, described in the field experiment of the years 2008-2010, on the specific and at the same time unique division of the population of RILs, performed using Ward's agglomerative method after the ending of the laboratory experiment (Smolik, 2013), no significant differences were found between means of most examined traits between the following groups of RILs: A, C and E (Fig. 2).

Higher values of traits were generally found for the lines of group $\mathrm{E}$ in comparison with groups $\mathrm{A}$ and $\mathrm{C}$, and the statistically significant trait was GWP (Fig. 2). In Fig. 2 , letters $B$ and $D$ denote means of the examined traits respectively for 14 lines in each group. They were selected among the RILs determined as susceptible (A) and tolerant (E) in the laboratory experiment (Smolik, 2013). The reason for presenting their characterization in comparison with means of A, C and E (Fig. 2), was the fact that they were also identified in groups of extreme lines (respectively 'a' and ' $f$ ') of Ward's dendrogram presented in Fig. 1. It was demonstrated that the groups of selected RILs were sig- nificantly different in terms of SL, GNS, SF, GWS, GWP (Fig. 2).

On the other hand, no significant differences were found for PH, PT, SNS and TGW, although the group of lines $\mathrm{D}$ was better in terms of TGW (Fig. 2).

The analysis of matrix of simple correlations determined between means of traits of the examined population of RILs showed great variability depending on both the values of the correlation coefficients ( $\mathrm{r}$ ), and their significance (Tab. 5). They were presented in detail in Tab. 5, indicating high values of correlation coefficients between GWS and GNS $\left(0.90^{* *}\right), S F$ and GNS $\left(0.89^{* *}\right)$ and low SL and PH $\left(0.21^{*}\right)$ or TGW and SL $\left(0.18^{*}\right)$ (Tab. 5).

The values of simple correlation coefficients $(r)$ between means of traits of seedlings of individual RILs analyzed under laboratory conditions were presented in some other paper (Smolik, 2013).

In the present study the means were used only for generation of matrix of simple correlations between traits of a mature plant $\left(\mathrm{F}_{8-10}\right)$ and traits of the seedlings examined in terms of response to nutrient stress under laboratory conditions $\left(\mathrm{F}_{7}\right)$. The values of correlation coefficients were low (data not shown). Positive significant correlations were found between $\mathrm{PH}$ and coleoptyle length of a seedling growing in a medium with high $\mathrm{N}$ and $\mathrm{K}$ content $(\mathrm{r}$

Tab. 5. Correlation matrix for agronomic traits of the RIL population

\begin{tabular}{|c|c|c|c|c|c|c|c|c|c|}
\hline Trait & $\mathrm{PH}$ & SL & PT & SNS & GNS & SF & GWS & GWP & TGW \\
\hline $\mathrm{PH}$ & 1.00 & & & & & & & & \\
\hline SL & $0.21^{*}$ & 1.00 & & & & & & & \\
\hline PT & 0.00 & $0.26^{* *}$ & 1.00 & & & & & & \\
\hline SNS & $0.26^{* *}$ & $0.82^{* *}$ & $0.20^{*}$ & 1.00 & & & & & \\
\hline GNS & 0.13 & 0.05 & -0.07 & $0.21^{*}$ & 1.00 & & & & \\
\hline SF & 0.01 & $0.32^{* *}$ & -0.15 & $-0.24^{* *}$ & $0.89^{* *}$ & 1.00 & & & \\
\hline GWS & $0.27^{* *}$ & 0.16 & 0.02 & $0.29^{* *}$ & $0.90^{* *}$ & $0.76^{* *}$ & 1.00 & & \\
\hline GWP & $0.24^{* *}$ & $0.24^{* *}$ & $0.34^{* *}$ & $0.31^{* *}$ & $0.79^{* *}$ & $0.63^{* *}$ & $0.82^{* *}$ & 1.00 & \\
\hline TGW & $0.37^{* *}$ & $0.18^{*}$ & 0.14 & 0.17 & $0.25^{* *}$ & 0.16 & $0.63^{* *}$ & $0.65^{* *}$ & 1.00 \\
\hline
\end{tabular}

Correlation coefficients were calculated for means of agronomic traits of RILs of the years 2008-2010, obtained as a result of analysis of variance for the years $2008-2010 .^{*}-p<0.05,{ }^{* *}-p<0.01$ significant different from zero 

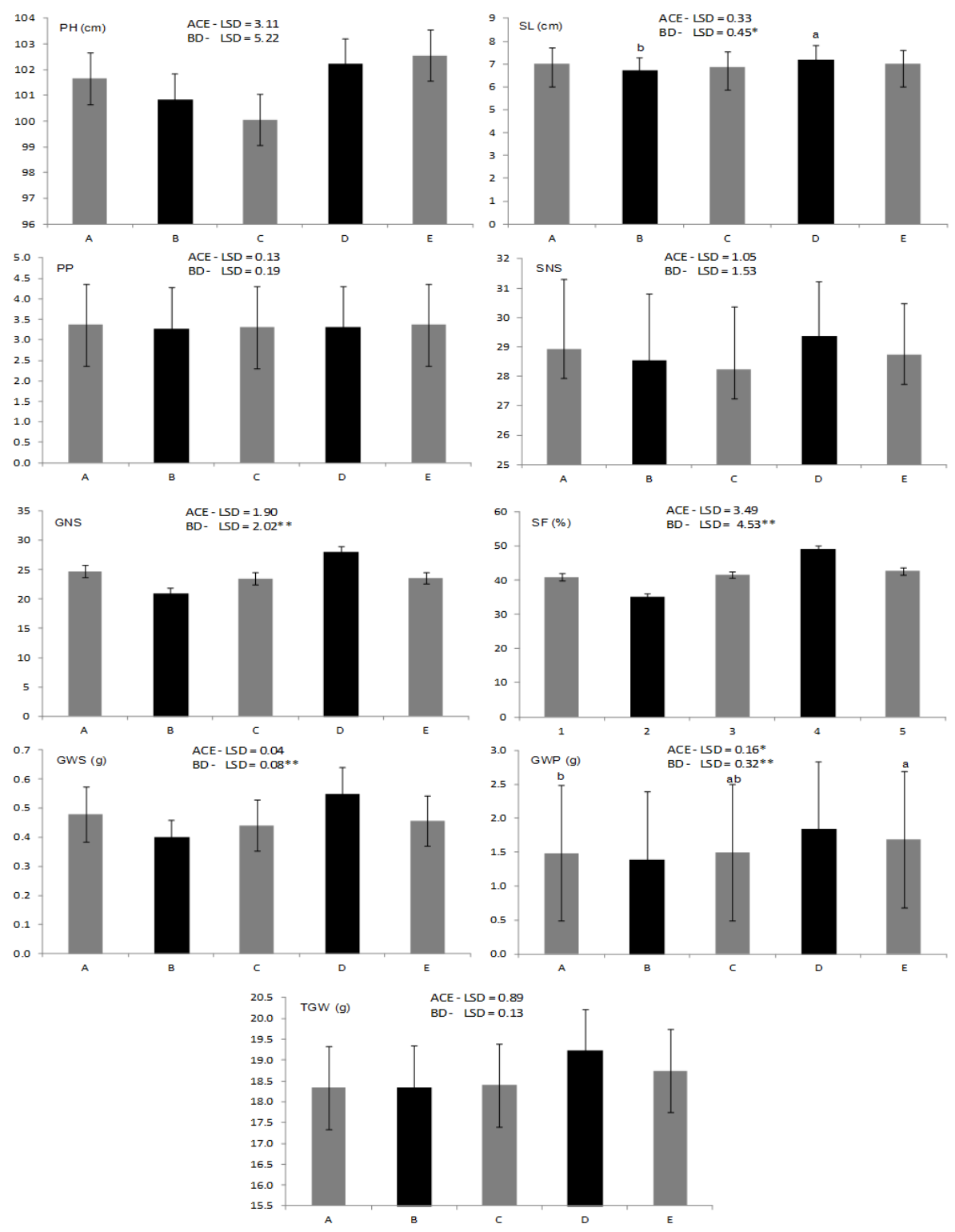

Fig. 2. Means of agronomic traits of the RILs examined in the field experiment in the years 2008-2010. For the groups of RILs denoted by letters A, C, E and B, D, description was placed in the text

PH - plant high; SL - spike length; PP - plant propagation; SNS - spikelet number per spike; GNS - grain number per spike, SF - spike fertility; GWS - grain weight per spike; GWP - grain weight per plant; TGW - 1000 grain weight. The charts show means and standard deviations (SD) of traits of the examined RILs. LSD values were calculated with the use of $\mathrm{t}$-Tukey's HSD test at ${ }^{*},{ }^{* *} p<0.05, p<0.01$, respectively. Letters ' $a$ ' and ' $b$ ' denote homogeneous groups

$\left.=0.18^{*}\right)$ as well as between $\mathrm{PH}$ and coleoptyle length of seedlings growing in a medium with nutrient deficiencies $\left(\mathrm{r}=0.19^{*}\right)$. In addition, positive, yet significant at $p<0.10$, correlations were noted between SNS $(r=0.14)$ and the longest root length (LRL) of seedlings, and also significant correlations were observed between SF and LRL of seedlings growing under conditions of nutrient deficiencies ( $\mathrm{r}$ $=0.19^{*}$ ). Positive significant correlations were found be- tween LRL and GWS $\left(\mathrm{r}=0.21^{*}\right)$, LRL and GWP $(\mathrm{r}=$ $\left.0.18^{*}\right)$ and between LRL and TGW $(r=0.13)$ at $p<0.10$. Also a significant correlation $(\mathrm{r}=0.14)$ was observed at $p$ $<0.10$ between LRL trait of seedlings growing in a high level of $\mathrm{N}$ and $\mathrm{K}$ in a medium and TGW. Some positive, yet statistically non significant correlations were demonstrated between root number $(\mathrm{RN})$ and PT. 
282

\section{Discussion}

Results of the field experiment, presented in this study, fall into the trend of research on revealing the genetic background of tolerance of cereals, including rye, to abiotic stresses (Masojć et al., 2009), including nutrient stress caused by nitrogen and potassium deficiencies assessed at the seedling stage obtained in vitro in mature embryos cultures (Rzepka-Plevneš and Kulpa, 1996; Rzepka-Plevneš et al., 1997a; 1997b), hydroponics and under field conditions (Rzepka-Plevneš and Tomczak, 1998).

The selection of parental components (Ot1-3 and 153/79-1) used for generation of $F_{2}$ hybrid, from which the population of 138 RILs $\left(\mathrm{F}_{8.10}\right)$ was derived, was conditioned by extremely different responses of lines to stress caused by nitrogen and potassium deficiencies in a medium (Rzepka-Plevneš et al., 1997a). The lines, as it was shown in the present research, differed significantly also in other agronomic traits, such as PH, SL, SNS, GNS or GWP. Line 153/79-1 is of different origin, shows different response to nutrient stress (Rzepka-Plevneš et al., 1997a) and has different profile of polypeptides - i.e. secalins, separated under the conditions of SDS-PAGE, when compared to line Ot1-3 (Smolik and Rzepka-Plevneš, 2003). Line Ot1-3 has been considered as a line non-tolerant to nitrogen and potassium deficiencies in a medium by Rzepka-Plevneš et al. (1997a). It was derived, as one of many inbred lines, by inbreeding of Otello, a Swedish cultivar requiring good stands, selected from one spike of an old population cultivar of rye - Kungs II with its known sensitivity to drought (Persson, 1976). The similar mechanisms of plant response to stress of drought and nutrient deficiencies (Ashraf and Harris, 2005) may confirm also research results by Rzepka-Plevneš et al. (1997a), describing inbred line Ot1-3 as susceptible to nutrient stress, and may only suggest the possibility of inheriting the genes that determine lack of tolerance to drought from its descendant cultivar Kungs II (Persson, 1976). On the other hand, inbred line Ot1-3 has low activity of $\alpha$-amylase and has been used as a maternal form - donor of resistance genes in research on sprouting in rye (Masojć et al., 2009, Milczarski et al., 2011).

In 2008 the highest mean PH (on average $110.8 \mathrm{~cm}$ ) for the examined population of RILs was noted in 2008, while in the subsequent years the means were lower. Apart from the potential influence of inbreeding per se on the examined trait (Wolski, 1970; Wricke, 1970), also influence of changing weather conditions, such as were noted in the years 2008-2010, cannot be excluded (Miziak et al., 2011). On the other hand, considerable shortening of plant height of rye may be achieved by inbreeding (Wolski, 1970; Wricke, 1970; Zamorska, 1968). According to the authors, inbreeding results in plant height shortening and at the same time has a various influence on spike length. Similar opinion has been shared by Patyna and Grochowski (1972), who reckon that inbreeding enables to break the correlation between the plant height and spike length (Górny et al., 1982; Łapiński, 1984).

The range of variability for SL ranged between 4.6 and $10.1 \mathrm{~cm}$ in the examined population of RILs, and on average for the years it amounted to $7 \mathrm{~cm}$. Similar results of observations were presented by Milczarski (2010). The author reported the range of variability for the three years of research (2004-2006) for PH at the level of 74-146 cm (on average $115 \mathrm{~cm}$ ) for the mapping population $(\mathrm{K})$ including 73 RILs $\left(\mathrm{F}_{6}\right)$ of rye, where the maternal component was line Ot1-3. In terms of SL the population $\mathrm{K}$ had the range of variability at the level from 5.5 to $13.2 \mathrm{~cm}$, amounting to $7.9 \mathrm{~cm}$ on average for the years (Milczarski, 2010).

Low variability was demonstrated for PT. The trait ranged from 2.1 to 5.5; on average for the years - 3.6 plants. Similar results for mean for the population $\mathrm{K}$ were presented by Milczarski (2010), describing the range of variability from 1.3 to 8.5 plants.

According to Kaczmarek and Pielas (1970) (from Słaboński et al., 1984) and Wricke (1970), SF of inbreeding rye genotypes ranges from 3 to $54 \%$ and depends on environmental conditions. Fertility of spikes per se at the level of $62-82 \%$ proves poor grain setting. In the present study SF in the examined population of RILs amounted to $13.8-67.6 \%$, on average $41.7 \%$. In a study by Milczarski (2010) the trait ranged between 2.2 and $82 \%$, reaching the mean of $41.3 \%$. In a study by Staboński et al. (1984), spike fertility for inbred rye lines $\left(\mathrm{S}_{6}\right)$ was from 3.2 to $55.7 \%$. Such large differences in SF may be explained by the effect of genes determining a self-incompatibility type of and lethal and sub-lethal loci in the homozygous state (Kaczmarek and Pielas, 1970; Wolski, 1970; Wricke, 1970).

Spike fertility is reflected in grain number per spike (GNS), and in a further stage in yield per spike (GWS), per plant (GWP) or TGW. GNS in the examined population of RILs ranged from 8 to 42 grains, on average 24. Similar observations for the population $\mathrm{K}$ was presented by Milczarski (2010). Mean grain yield per spike of the examined population of RILs amounted to $0.5 \mathrm{~g}$, in the population $\mathrm{K}-0.44 \mathrm{~g}$ (Milczarski, 2010), and yield per plant (GWP) in the examined population on average for the years of research amounted to $1.6 \mathrm{~g}$, and in the population $\mathrm{K}-1.5 \mathrm{~g}$ (Milczarski, 2010). Problems with fertility and number of grains per spike in the genotypes of the mapping populations for rice have been described by Xing et al. (2002) and for wheat by Kumar et al. (2007).

Studies by Zamorska (1968), Wricke (1970), Kaczmarek and Pielas (1970) demonstrate that a decrease in TGW has been observed from the first to the third year of inbreeding. However, according to Staboński et al. (1984), decreasing TGW in inbred lines of rye may be observed also in w $\mathrm{S}$. The inbred lines examined by Staboński et al. (1984) had TGW of $33 \mathrm{~g}$, while inbred lines of rye in a study by Zamorska (1968) 18 - 28g. In the present study on average the lowest TGW values were found for RILs of the examined population in research year 2009. The de- 
crease in TGW might have resulted from adverse weather conditions (Miziak et al., 2011). The effect of unfavorable weather conditions (including dry and very hot weather) on the value of this trait has been described in many studies (Staboński et al., 1984). Unfavorable weather results in fast generation of grains and their worse filling, which causes decreased TGW. In the present study TGW was at the level of 12.6 - $28 \mathrm{~g}$, on average $18.6 \mathrm{~g}$, and in the population K - $17.2 \mathrm{~g}$ (Milczarski, 2010).

The population of recombinant inbred lines of rye examined in the present study led to the $\mathrm{F}_{8-10}$ generation should be considered genetically stable, with segregation within a single locus at the level of 1:1. Exceeding the level of variability found in the population of RILs, exceeding the range of the traits of parental components, may be explained by the transgression effect. The changes of traits observed in the population of RILs, examined in the years, may be accounted for the influence of environmental factors and also fluctuations of the examined traits (Miziak et al., 2011), occurring during inbreeding $\left(\mathrm{F}_{3-7}\right)$, and revealed in the present research as 'continuation through inheritance' of already stabilized effects of segregation of individual loci.

The heterosis effect has been described for $\mathrm{F}_{1}$ hybrid, obtained in a combination of crossings of lines 153/79-1 $\times$ Ot1-3. $F_{1}$ hybrid significantly outdid the lines in terms of each trait, which was demonstrated for PT, GNS, SF, GWS, GWP or TGW.

Correlation coefficients for agronomic traits, presented in the present study for RILs of rye, are in accordance with the results of research presented for the same traits by Górny et al. (1982), Rzepka-Plevneš et al. (1997b), Rzepka-Plevneš and Tomczak (1998), Rzepka-Plevneš and Kulpa (1996) and Milczarski (2010). Significantly positive correlations for the following traits: $\mathrm{PH}$ and SL, GNS, TGW, were shown for inbred lines of rye by Górny et al. (1982). They amounted to $\mathrm{r}=0.49^{* *}, \mathrm{r}=0.28^{*}, \mathrm{r}=$ $0.38^{*}$, respectively. For the populations of rye examined in a pot experiment, selected in in vitro cultures from openpollinated varieties of rye, Rzepka-Plevneš et al. (1997b) described them respectively as: $\mathrm{r}=0.23^{*}, \mathrm{r}=0.17^{* *}, \mathrm{r}=$ $0.49^{* *}$. For the population $\left(S_{1}\right)$ of rye, selected in hydroponics from open-pollinated varieties of rye, RzepkaPlevneš and Tomczak (1998), presented them as $\mathrm{r}=$ $0.36^{* *}, r=0.15^{*}, r=0.43^{* *}$. Rzepka-Plevneš and Kulpa (1996) assessed the correlations for populations (S1 and S2), selected in in vitro cultures from open-pollinated varieties of rye, at the level of $\mathrm{r}=0.03, \mathrm{r}=0.03$ and $\mathrm{r}=$ $0.46^{* *}$, while Milczarski (2010) determined them at the level of $r=0.52^{* *}, r=0.27^{* *}$ and $r=0.20^{* *}$ for the population $\mathrm{K}$. In the present study the coefficients amounted to $0.21^{* *}, 0.19^{*}$ and $0.37^{* *}$, respectively. Similar correlations were described respectively between: SL and GWS, GWP and TGW in the papers by Górny et al. (1982), Rzepka-
Plevneš et al. (1997b), Rzepka-Plevneš and Tomczak (1998), Rzepka-Plevneš and Kulpa (1996) and by Milczarski (2010) for the population K. It should be pointed, that the correlation coefficients higher than 0.3 are agronomically important.

Correlation relationships, described between the selected traits of the seedlings of RILs of rye, examined under laboratory conditions, and traits of a mature plant, described in the field experiment, were relatively low and often significant only at $p<0.10$. However, according to the author they confirm the opinions of many authors on relationships between development of traits of seedlings and of a mature plant. For rye they were presented by Górny and Geiger (1982), Górny et al. (1982) and Łapiński (1984).

Against a background of the conducted experiment, (significantly) positive correlations between the chosen traits of the seedlings of RILs selected for tolerance to nutrient deficiencies, assessed with the use of morphological criteria of seedlings-the longest root length or root number in in vitro cultures of mature embryos (RzepkaPlevneš and Kulpa, 1996; Rzepka-Plevneš et al., 1997a, b), and traits of a mature plant, described for the population of RILs in the present experiment, may confirm the usefulness of laboratory research for selection of genotypes with increased tolerance to stress caused by nutrient deficiencies (Górny and Szołkowska, 1996; Rzepka-Plevneš and Kulpa, 1996; Rzepka-Plevneš et al., 1997b).

Ward's method of agglomeration on the basis of grouping variables, determining the economical value of a rye inbred line, was used to demonstrate the possibility of formation of extreme groups of the examined RILs - and to select the lines identified also in the extreme groups obtained for the population analyzed under laboratory conditions (Smolik, 2013). As it has been shown, the lines differed significantly in terms of most examined traits.

Each laboratory method has its limitations and in order not to draw too hasty conclusions, the limitations should be taken into account. They were presented only for in vitro cultures in a very good review by Hazarika (2006). Additionally, an interesting verification of the obtained results can be carried out after identification of QTLs of the described agronomic traits and comparing them with the results of research presented by Milczarski (2010) and Milczarski et al. (2011). What is more, identification of QTLs of biometric traits of seedlings analyzed under both low and high level of nitrogen and potassium can be attempted, and the results can be compared to the QTLs described for root architecture of plants growing under conditions of different abiotic stresses by Tuberosa et al. (2002), Mano et al. (2006), Zhu et al. (2005), Liu et al. (2008), including the conditions of nitrogen deficiencies (Tuberosa and Salvi, 2007). 
284

\section{Conclusions}

Inbred lines of rye selected as parental components of the population of RILs differ in most agronomic traits, and the heterosis effect is observed in their $F_{1}$ hybrid. A range of variability exceeding the variability described for the traits of parental lines is observed in the population of one hundred thirty-eight RILs. This fact confirms the transgression effect. The existing correlation relationship for agronomic traits of RILs enables selection of lines with definite properties. Positive and often significant correlations between traits of seedlings and selected agronomic traits of a mature plant of examined RILs provide the opportunity for selection of lines tolerant to nutrient stress. Their usefulness for breeding may be assessed only in topcross experiments or in construction of other mapping populations and verification of obtained QTLs after their previous phenotyping.

\section{Acknowledgements}

This work was supported by the Polish Ministry of Science and Higher Education under grant No. N N302 281936. The author wishes to thank J. Kurek, MSc and M Krupa-Małkiewicz, $\mathrm{PhD}$ for help and efficient assistance during the experiments.

\section{References}

Aniol A, Gustafson JP (1984). Chromosome location of genes controlling aluminum tolerance in wheat, rye and triticale. Can Agron J 91:357-363.

Arseniuk E, Oleksiak T (2003). Rye production and breeding in Poland. Plant Breed Seed Sci 47(1/2):7-16.

Ashraf M, Harris PJC (2005). Abiotic stresses plant resistance through breeding and molecular approaches. Food Products Press, New York, PT, 1-725 p.

Bloom AJ, Chapin FS, Mooney HA (1985). Resource limitation in plants an economic analogy. Ann Rev Ecol Syst 16:363-392.

Bolanõs J, Edmeades GO, Martinez L (1993). Eight cycles of selection for drought tolerance in lowland tropical maize. III. Responses in drought-adaptive physiological and morphological traits. Field Crops Res 31:269-286.

Ciepły J, Oracka T (2000). Dry matter accumulation, nitrogen and phosphorus uptake in winter triticale genotypes differing in mineral elements utilization efficiency. Plant Breed Seed Sci 44(1):3-13.

Dmochowska H (Ed.) (2011). Concise statistical yearbook of Poland. Year LIV. Statistical Publishing Establishment, Warsaw 2011, PT, 317, 336 p.

Geiger HH, Miedaner T (2009). Rye breeding, 157-181 p. In: Carena MJ (Ed.). Cereals (Handbook of Plant Breeding), Vol. 3, $1^{\text {st }}$ edn, Springer, New York, PT.

Górny AG (1995) Direct effect of cyclic selection for longer seminal roots in spring barley (Hordeum vulgare L.). J Appl
Genet 36(1):17-26.

Górny AG, Banaszak Z, Ługowska B, Ratajczak D (2011). Inheritance of the efficiency of nitrogen uptake and utilization in winter wheat (Triticum aestivum L.) under diverse nutrition levels. Euphytica 177:191-206.

Górny AG, Szołkowska A (1996). Effects of selection for more vigorous seminal roots in two cross populations of oat (Avena sativa L.). J Appl Genet 37(4):331-344.

Górny AG, Geiger HH (1982). Variation and covariation among juvenile shoot and root characters of inbred lines and hybrids in rye (Secale cereale L.). Berlin, Tagungsbericht, Akad. Landwirtsch. Wiss. DDR:445-454.

Górny AG, Geiger HH, Morgenstern K, Singh RK (1982). Correlations between seedling and adult plant characters in hybrids and inbred lines of rye (Secale cereale L.). Berlin, Tagungsbericht, Akad. Landwirtsch. Wiss. DDR:389-399.

Hazarika BN (2006). Morpho-physiological disorders in in vitro culture of plants. Sci Hort 108:105-120.

Kaczmarek J, Pielas Z (1970). Effect of inbreeding on fertility in rye, grain weight, percentage of protein in the grain. Biul Inst Hod Aklim Rośl 3-4:41-43.

Kumar N, Kulwal PL, Balyan HS, Gupta PK (2007). QTL mapping for yield and yield contributing traits in two mapping populations of bread wheat. Mol Breed 19(2):163-177.

Lammerts van Bueren ET, Backes G, de Vriend H, Østergard H (2010). The role of molecular markers and marker assisted selection in breeding for organic agriculture. Euphytica 175:51-64.

Łapiński M (1984). Relationships between some seedling and mature plant traits in rye. Zeszyty Naukowe Akademii Rolniczej w Szczecinie. Rolnictwo seria XXXV 110:23-34. (in Polish)

Liu J, Li J, Chen F, Zhang F, Ren T, Zhuang Z, Mi G (2008). Mapping QTLs for root traits under nitrate levels at the seedling stage in maize (Zea mays L.). Plant Soil 305:253265.

Löschenberger F, Fleck A, Grausgruber H, Hetzendorfer H, Hof G, Lafferty J, Marn M, Neumayer A, Pfaffinger G, Birschitzky J (2008). Breeding for organic agriculture-the example of winter wheat in Austria. Euphytica 163:469-480.

Lynch JP (2007). Roots of the second green revolution. Aust J Bot 55:493-512.

Malamy JE (2005). Intristic and environmental response pathways that regulate root system architecture. Plant Cell and Environ 28:67-77.

Mano Y, Muraki M, Takamizo T (2006). Identification of QTL controlling flooding tolerance in reducing soil conditions in maize (Zea mays L.) seedlings. Plant Prod Sci 9:176-181.

Masojć P, Lebiecka K, Milczarski P, Wiśniewska M, Łań A, Owsianicki R (2009). Three classes of loci controlling preharvest sprouting in rye (Secale cereale L.) discerned by means of bidirectorial selective genotyping (BSG). Euphytica 170:123-129. 
Messmer M, Hildermann I, Thorup-Kristensen K, Rengel Z (2011). Organic crop breeding: Nutrient management in organic farming and consequences for direct and indirect selection strategies, Organic crop breeding. Lammerts van Bueren ET, Myers JR (eds), Blackwell \& Wiley:21-27.

Milczarski P (2010). The identification and comparative mapping of QTLs controlling selected quantitative traits in two mapping populations of rye (Secale cereale L.). The habilitation thesis, West Pomeranian University of Technology in Szczecin, Szczecin.

Milczarski P, Bolibok-Brągoszewska H, Myśków B, Stojałowski S, Heller-Uszyńska K, Góralska M, Brągoszewski P, Uszyński G, Kilian A, Rakoczy-Trojanowska M (2011). High density consensus map of rye (Secale cereale L.) based on DArT Markers. PLoS ONE 6(12): e28495. doi:10.1371/journal. pone.0028495.

Miziak K, Pudełko R, Kozyra J, Nieróbca A, Doroszewski A, Świtaj Ł, Łopatka A (2011). Results of monitoring agricultural drought in winter wheat crops in Poland in the years 2008-2010. Water-Environment-Rural Areas vol. 11, 2(34):95-107 (in Polish).

Patyna H, Grochowski L (1972). Inbreeding as a method to search for new traits in rye. Biul IHAR 5-6:65-72.

Persson T (1976). Otello - a result of amylase selection for sprouting resistance. Cereal Res Com 4(2):101-106.

Rapacz M, Kościelniak J, Jurczyk B, Adamska A, Wójcik M (2010). Different patterns of physiological and molecular response to drought in seedlings of malt- and feed-type barleys (Hordeum vulgare). J Agron Crop Sci 196(1):9-10.

Rapacz M, Wolanin B, Hura K, Tyrka M (2008). The effects of cold acclimation on photosynthetic apparatus and the expression of COR $14 \mathrm{~b}$ in four genotypes of barley (Hordeum vulgare) contrasting in their tolerance to freezing and highlight treatment in cold conditions. Ann Bot 101:689-699.

Raun WR, Johnson GV (1999). Improving nitrogen use efficiency for cereal production. Agron J 91:357-363.

Rzepka-Plevneš D, Łapiński M, Tomczak P (1990). Agronomic properties of $\mathrm{BC}_{2}$ interspecific rye hybrids. Hod Rośl i Ak$\lim \operatorname{Nas} 34(5 / 6): 61-72$ (in Polish).

Rzepka-Plevneš D, Kulpa D (1996). The tolerance of some interspecies rye hybrids to nutrition deficiency under laboratory conditions. Genet Pol 37A:231-234.

Rzepka-Plevneš D, Marciniak H, Śmiech M (1997a). The evaluation of rye $(S$. cereale $\mathrm{L}$.) inbred lines tolerance to nutrition deficiency by in vitro test. Biul IHAR 203:137-146 (in Polish).

Rzepka-Plevneš D, Tomczak P (1998). Agronomic properties of rye populations selected for tolerance to nitrogen deficiency in hydroponic cultures. Plant Breed Seed Sci 42(2):65-74
Rzepka-Plevneš D, Kurek J, Marciniak H (1997a). Agronomic properties of rye forms selected in vitro for tolerance to nutrient deficiency. Plant Breed Seed Sci 41(2):91-100.

Sayar R, Bchini H, Mosbahi M, Khemira H (2010). Response of durum wheat (Triticum durum Desf.) growth to salt and drought stresses. Czech J Genet Plant Breed 46(2):54-63.

Słaboński A, Rzepka D, Pieniążek B (1984). Possibilities of using interspecies hybrids of Secale cereale $\times S$. montanum, $S$. cereale $\times S$. kuprianovii and $S$. cereale $\times S$. vavilovii in rye breeding. Hod Roś Aklim Nas 28(2):195-210. (in Polish).

Smolik M, Rzepka-Plevneš D (2003). Evaluation of genetic variation of inbred lines and a degree of hybridity of rye by SDS-PAGE method. Biul IHAR 226/227/2: 309-317. (in Polish)

Smolik M (2013). Screening and discrimination of population of recombinant inbred lines of rye (Secale cereale L.) for different response to nitrogen-potassium stress assessed at the seedling stage under in vitro conditions. Electron J Biotechn 16(1) doi: 10.2225/vol16-issue1-fulltext-5

Tsay YF, Ho CHH, Chen HY, Lin SH (2011). Integration of nitrogen and potassium signaling. Ann Rev Plant Biol 62:207-226.

Tuberosa R, Salvi S, Sanguineti MC, Landi P, Maccaferri M, Conti S (2002). Mapping QTLs regulating morpho-physiological traits and yield: case studies, shortcomings and perspectives in drought-stressed maize. Ann Bot 89:941-963.

Tuberosa R, Salvi S (2007). From QTLs to genes controlling root traits in maize, 13-22 p. In: Spiertz JHJ, Struik PC, van Laar HH (Eds.). Scale and complexity in plant systems research: gene-plant-crop relations. Springer.

Wolfe MS, Baresel JP, Desclaux D, Goldringer I, Hoad S, Kovacs G, Löschenberger F, Miedaner T, Østergård H, Lammerts van Bueren ET (2008). Developments in breeding cereals for organic agriculture. Euphytica 163:323-346.

Wolski T (1970). Studies in the inbreeding of rye. Genet Pol 11:1-26.

Wricke G (1973). Inzuchtdepression und Genwirkung beim Roggen (Secale cereale). Theor Appl Genet 43:83-87.

Xing YZ, Tan YF, Hua JP, Sun XL, Xu CG et al. (2002). Characterization of the main effects, epistatic effects and their environmental interactions of QTLs in the genetic basis of yield traits in rice. Theor Appl Genet 105:248-257.

Zamorska M (1968). Results of studies on rye inbreeding ( $\mathrm{Se}$ cale cereale L.). Zesz. Nauk. WSR Wrocław 77:83-103.

Zhu JM, Kaeppler SM, Lynch JP (2005a). Mapping of QTLs for lateral root branching and length in maize (Zea mays L.) under differential phosphorus supply. Theor Appl Genet 111:688-695. 